\title{
INFLUENCE OF THE RELEASE TIME AND METEOROLOGICAL CONDITIONS ON THE FORMATION OF SECONDARY POLLUTANTS IN COAL-FIRED POWER-STATION PLUMES
}

A multibox reactive plume model (MRPM) was used to examine the influence of both the release time of pollutants to the atmosphere and meteorological conditions characterised by the atmospheric stability and wind velocity on the formation of secondary pollutants in conventional power-station plumes. Meteorological conditions were typical of a summer, sunshine day in Poland. Calculations were carried out for two release times, i.e. 7:00 and 13:00. In the analysis, hydroxyl and peroxyl radicals $(\mathrm{OH}$ and $\left.\mathrm{HO}_{2}\right)$ and photochemical oxidants of ozone and peroxyacetyl nitrate $\left(\mathrm{O}_{3}\right.$ and PAN) were considered. Results of the computer studies confirmed that there was the dependence of the reactive plume evolution on the parameters studied. Of all the parameters considered the time of the pollutant release to the atmosphere had the strongest influence on the formation of secondary pollutants in the power station plumes.

\section{INTRODUCTION}

Conventional power stations emit to the atmosphere great amounts of gaseous pollutants of which sulphur dioxide $\left(\mathrm{SO}_{2}\right)$ and nitrogen oxides $\left(\mathrm{NO}_{x}\right)$ predominate. Plume constituents, while mixing with an ambient air, react with other pollutants such as hydrocarbons present in the atmosphere. As a result the secondary pollutants such as ozone $\left(\mathrm{O}_{3}\right)$, peroxyacetyl nitrate (PAN), aerosols of nitrogen and sulphuric acid $\left(\mathrm{HNO}_{3}\right.$ and $\left.\mathrm{H}_{2} \mathrm{SO}_{4}\right)$ are formed in the plumes. These secondary species are now thought to be more harmful to human health and environment than the pollutants emitted directly to the atmosphere. The formation of secondary species in the atmos-

${ }^{*}$ Technical University of Warsaw, Department of Environment Engineering, Institute of the Systems of Enviroment Engineering, ul. Nowowiejska 20, 00-653 Warszawa, Poland. 
phere is more intensive in summer days with sunshine and warm weather. Under these conditions the intensity of the photochemical reactions increases.

Reactive plume models were developed to study the evolution of reactive plumes emitted from conventional power stations. Examples of such models and results of the computer simulations carried out using these models are described in the papers of HOV and ISAKSEN [1], STEWARD and LIU [2] and DERWENT [3]. A review of the reactive plume models is given in the report by MARKIEWICZ [4].

The objective of this study was to examine the influence of environmental conditions such as the release time of pollutants to the atmosphere and meteorological conditions on the formation of secondary pollutants in the coal-fired power-plant plumes. In the simulations, a multibox reactive plume model (MRPM) described in detail by MARKIEWICZ [5] was used. Calculations were done for meteorological conditions typical of a sunny, summer day in Poland. In the paper first a short characteristic of the MRPM model is given. Next, the mechanisms of the secondary pollution formation in the atmospheric boundary layer are described. Finally, a description of an input of data into the MRPM model and results of the computer simulations carried out by means of this model are presented.

\section{MODEL DESCRIPTION}

The MRPM model visualises a cross section of the plume as an array of wellmixed boxes which is perpendicular to the plume centre line. Dimensions of this array, i.e. its width and depth, increase as the array moves downwind along the plume trajectory. Concentrations of pollutants in each box are calculated within a Lagrangian framework, i.e. as the plume moves with the wind, based on the set of mass conservation equations of the form [5]:

$$
\frac{d C_{i}{ }^{j}}{d t}=\frac{a l f_{w, l+1}}{w_{\mathrm{b}} n_{\mathrm{b}}} C_{i}{ }^{j}-\frac{a l f_{u, l+1}}{h_{\mathrm{b}}}\left(C_{i}{ }^{j}-C_{i, u}\right)-\frac{a l f_{g, l+1}}{h_{\mathrm{b}}}\left(C_{i}{ }^{j}-C_{j, g}\right)+F_{i}^{j}+R_{i}^{j}+P_{i}^{j}+S_{i}^{j}(1)
$$

where $C_{i}^{j}, C_{i, u}$ and $C_{i, g}$ denote instantaneous concentrations of the chemical species $i$ in the $j$ box and in the ambient air below and above the plume boundary, respectively (molecule $\left./ \mathrm{m}^{3}\right) ; w_{\mathrm{b}}$ and $h_{\mathrm{b}}=h_{\mathrm{p}}$ are the width and depth of the box $(\mathrm{m}) ; n_{\mathrm{b}}$ is the number of boxes into which the plume cross section was divided; $a l f_{w, l+1}$ is the expansion rate coefficient in the horizontal direction $(\mathrm{m} / \mathrm{s}) ;$ alf $_{u, l+1}$ and alf $_{g, l+1}$ are the expansion rate coefficients in the vertical direction for the upper and lower plume boundaries, respectively $(\mathrm{m} / \mathrm{s})$. The last four terms are expressed in molecule $/ \mathrm{cm}^{3} \cdot \mathrm{s}$ and describe net mass transfer across the box boundaries, the change of concentrations due to chemical reactions, dry deposition and emission of pollutants from all other sources localised in the area considered, i.e. from area ground level sources, respectively. 
The model MRPM is based on the traditional description of atmospheric stability, i.e. on discrete stability classes. The meteorological data cover the following parameters: atmospheric stability according to IMGW classes (the IMGW classification corresponds to the Pasquil-Gifford stability classification), wind velocity at the anemometer height and depth of the mixing layer. The mean velocity of the plume transport and plume dispersion are calculated based on the methodology described in Guidance of calculating the state of the air pollution contamination in the vicinity of point emission sources [6].

The parametrisation of chemical transformation processes is based on a scheme originally developed by DERWENT and HOV [7]. It describes processes which take place in homogeneous gas phase and occur between the following primary pollutants: $\mathrm{CO}, \mathrm{NO}_{x}$, $\mathrm{SO}_{2}$ and hydrocarbons. The number of chemical equations reaches one hundred. In the case of photochemical reactions, i.e. the reactions in which solar radiation is indispensable, the photolysis rates are parametrised as a function of a solar zenith angle. The parametrisation of dry deposition processes is based on a deposition rate $V_{d}$ [3]. The rates of dry deposition for $\mathrm{SO}_{2}, \mathrm{NO}_{2}, \mathrm{O}_{3}, \mathrm{PAN}$ and $\mathrm{HNO}_{3}$ were taken after GARLAND [8].

The MRPM model allows us to calculate the concentrations of such primary species as: $\mathrm{SO}_{2}, \mathrm{NO}, \mathrm{NO}_{2}$ and such secondary pollutants as: ozone, PAN as well as aerosols of $\mathrm{HNO}_{3}$ and $\mathrm{H}_{2} \mathrm{SO}_{4}$. The MRPM model is implemented in a FACSIMILE language [9]. It is the language developed especially to integrate a set of stiff differential equations, i.e. a system involving both rapidly changing terms as well as slowly varying terms.

\section{SUMMARY OF THE CHEMICAL MECHANISM \\ OF SECONDARY POLLUTANTS' FORMATION IN THE ATMOSPHERIC BOUNDARY LAYER}

The key chemical reactions occurring in gaseous phase and determining the daylight concentrations of radicals and secondary species such as ozone, PAN, nitric and sulphuric acids are summarised by equations (R.1) to (R.13) [10], [11]. Ozone is produced in the atmospheric boundary layer by reactions (R.1). Once formed $\mathrm{O}_{3}$ reacts with $\mathrm{NO}$ to regenerate $\mathrm{NO}_{2}$ according to reaction (R.2).

$$
\begin{gathered}
\mathrm{NO}_{2} \underset{\mathrm{O}_{2}}{\stackrel{h v}{\rightarrow}} \mathrm{NO}+\mathrm{O}_{3}, \\
\mathrm{NO}+\mathrm{O}_{3} \rightarrow \mathrm{NO}_{2}+\mathrm{O}_{2} .
\end{gathered}
$$

Formation of larger amounts of ozone depends upon the conversion of NO into $\mathrm{NO}_{2}$ without consumption of ozone. This is accomplished by the production of $\mathrm{HO}_{2}$ from hydrocarbons ( $\mathrm{RH})$ due to tropospheric oxidation, principally by $\mathrm{OH}$. The steps of chemical degradation of hydrocarbons are illustrated by reactions (R.3)-(R.5). It is important to notice that in this chain reaction, the $\mathrm{OH}$ radical, which starts the se- 
quence, is recovered at the end of it to carry out further oxidation. ' $\mathrm{RO}_{2}$ ' stands for organic peroxyl radicals.

$$
\begin{gathered}
\mathrm{OH}+\mathrm{RH} \stackrel{\mathrm{O}_{2}}{\rightarrow} \mathrm{RO}_{2}+\mathrm{H}_{2} \mathrm{O}, \\
\mathrm{RO}_{2}+\mathrm{NO} \stackrel{\mathrm{O}_{2}}{\rightarrow} \mathrm{R}^{\prime} \mathrm{CHO}+\mathrm{NO}_{2}+\mathrm{HO}_{2}, \\
\mathrm{HO}_{2}+\mathrm{NO} \rightarrow \mathrm{OH}+\mathrm{NO}_{2} .
\end{gathered}
$$

The cycle of hydrogen degradation is interrupted by the reactions of radical termination (R.6)-(R.10). Reactions (R.6) and (R.7) occur at low NO concentrations, while reactions (R.8) and (R.10) proceed at high $\mathrm{NO}_{2}$ concentrations with respect to hydrocarbon $(\mathrm{RH})$ concentrations.

$$
\begin{gathered}
\mathrm{HO}_{2}+\mathrm{HO}_{2} \rightarrow \mathrm{H}_{2} \mathrm{O}_{2}+\mathrm{O}_{2}, \\
\mathrm{RO}_{2}+\mathrm{HO}_{2} \rightarrow \mathrm{RO}_{2} \mathrm{H}+\mathrm{O}_{2}, \\
\mathrm{OH}+\mathrm{NO}_{2} \rightarrow \mathrm{HNO}_{3}, \\
\mathrm{OH}+\mathrm{SO}_{2} \underset{\mathrm{H}_{2} \mathrm{O}}{\stackrel{\mathrm{O}_{2}}{\rightarrow}} \mathrm{H}_{2} \mathrm{SO}_{4}+\mathrm{HO}_{2}, \\
\mathrm{RCHO}+\mathrm{OH} \underset{\mathrm{NO}_{2}}{\rightarrow} \mathrm{PAN} .
\end{gathered}
$$

The concentrations of radicals are determined based on the balance between radical sources and oxidants together with reactions which interconvert various radical species. The main source of $\mathrm{OH}$ radicals is the photolysis of ozone (R.11).

$$
\mathrm{O}_{3} \underset{\mathrm{H}_{2} \mathrm{O}}{\stackrel{h v}{\rightarrow}} 2 \mathrm{OH}+\mathrm{O}_{2} .
$$

Photolysis of formaldehyde (RCHO) (R.12) and photolysis of higher aldehydes are the main sources of $\mathrm{HO}_{2}$ during the daylight hours:

$$
\mathrm{RCHO} \underset{\mathrm{O}_{2}}{\stackrel{h v}{\rightarrow}} \mathrm{R}+\mathrm{HO}_{2}+\mathrm{CO} .
$$

Formation of aerosols of $\mathrm{HNO}_{3}$ and $\mathrm{H}_{2} \mathrm{SO}_{4}$ (R.8 and R.9) as well as formation of PAN (R.10) are considered as the processes of $\mathrm{OH}$ radical removal. The reactions of 
$\mathrm{HO}_{2}$ radical termination are given by equations (R.6) and (R.7). The main interconversion processes between the $\mathrm{OH}$ and $\mathrm{HO}_{2}$ radicals are represented by reactions (R. 5) and (R.13)

$$
\mathrm{OH}+\mathrm{CO} \stackrel{\mathrm{O}_{2}}{\rightarrow} \mathrm{HO}_{2}+\mathrm{CO}_{2}
$$

\section{INPUT DATA}

All simulations were carried out for a sunny, unclouded, summer day. In the calculations, two times of plume release, i.e. 7:00 and 13:00, were considered. Meteorological conditions covered three classes of atmospheric stability: very unstable, stable and slightly stable, three wind velocities: $3 \mathrm{~m} / \mathrm{s}, 4 \mathrm{~m} / \mathrm{s}, 5 \mathrm{~m} / \mathrm{s}$ and a mixing height of $1300 \mathrm{~m}$. The sun declination relevant to $21 \mathrm{st}$ of June and a latitude of $50^{\circ} \mathrm{N}$ were assumed. The plume was traced until late afternoon hours. In the calculations, the solar radiation intensity and background pollutant concentrations changed in time. The atmospheric stability, wind speed and height of the mixing layer were assumed constant during the whole period of plume tracing. These assumptions are acceptable to qualitative comparisons described herein. The aim of this study was to examine general trends rather than to calculate pollutant concentrations under a specific set of circumstances.

In the calculations, the parameters of the point emission source were assumed to be typical of a middle-size coal-fired power plant. The height and diameter of stack were equal to $100 \mathrm{~m}$ and $6 \mathrm{~m}$, respectively. The gas velocity and temperature at the stack exit had the values of $5 \mathrm{~m} / \mathrm{s}$ and $420 \mathrm{~K}$, respectively. Emission rates for $\mathrm{SO}_{2}, \mathrm{NO}$ and $\mathrm{NO}_{2}$ were assumed to be equal to: $1.29 \cdot 10^{25}$ molecule/s $(0.68 \mathrm{~kg}(\mathrm{~S}) / \mathrm{s}), 4.34 \cdot 10^{24}$ molecule $/ \mathrm{s}(0.1 \mathrm{~kg}(\mathrm{~N}) / \mathrm{s})$, and $2.17 \cdot 10^{23}$ molecule $/ \mathrm{s}(0.005 \mathrm{~kg}(\mathrm{~N}) / \mathrm{s})$, respectively. Emission rates of $\mathrm{CO}, \mathrm{NO}_{x}, \mathrm{SO}_{2}$ and hydrocarbons for ground level area sources characterise the urban atmosphere [3].

The analysis described herein involves the following species: $\mathrm{O}_{3}, \mathrm{PAN}, \mathrm{OH}, \mathrm{HO}_{2}$. Ozone and PAN represent the photochemical oxidants formed in the atmosphere. Hydroxyl and peroxyl radicals allow us to evaluate the potential for the hydrocarbon degradation.

\section{SIMULATION RESULTS}

Results of the simulations obtained from the MRPM model are presented graphically in two ways. Either the concentrations of species in the plume axis and ambient air are shown as a function of time or the distributions of species across the plume are presented at different times of the plume ageing. In the simulations the plume is represented by twenty boxes. Due to symmetry of the plume species the concentrations are calculated only in ten boxes. The eleventh box represents species concentrations in the ambient air. 


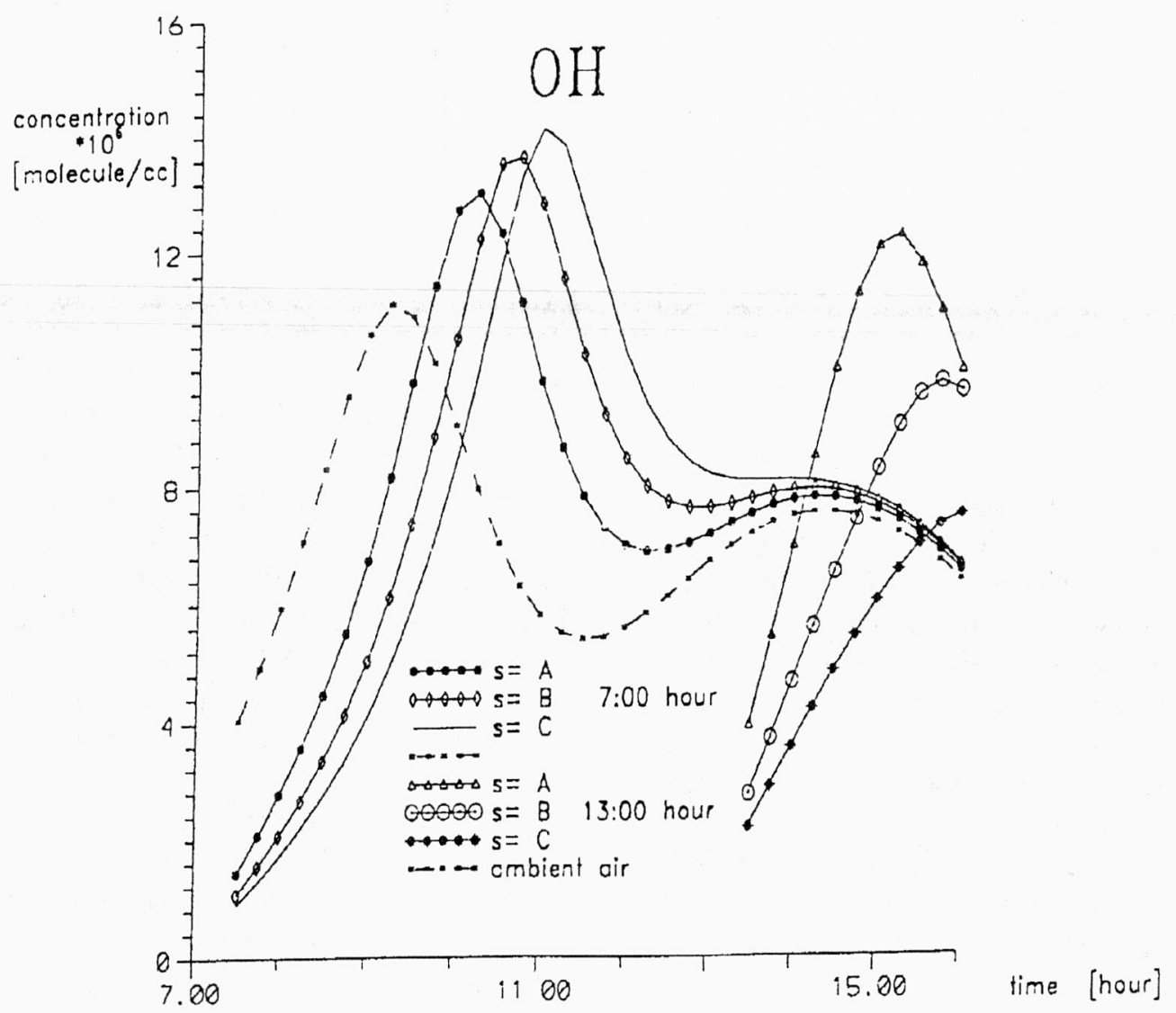

Fig. 1. Distribution of instantaneous $\mathrm{OH}$ concentration in the downwind plume axis for various atmospheric stabilities (s: very unstable $-A$, unstable $-B$, slightly unstable $-C$ ) and the wind velocity of $3 \mathrm{~m} / \mathrm{s}$. Pollutants were emitted from the stack at 7:00 and 13:00

The hydroxyl distributions of radical concentration are shown in figures $1,2,3$. The $\mathrm{OH}$ concentration in the plume axis initially grows rapidly with the travel time and quickly exceeds the background $\mathrm{OH}$ concentration. The peak of the $\mathrm{OH}$ concentration is reached few hours after the plume discharge. At the later stages the $\mathrm{OH}$ plume axis concentration decreases relatively quickly to the background value (figures 1,2). The $\mathrm{OH}$ concentration distribution across the plume changes as a function of time. The full plume development covers three stages: the initial stage with depletion and minimum at the centre line, the second stage with the establishment of an active fringe region, while the centre lags behind and finally the stage with maximum at the plume centre (figure 3). Analysing the distributions of $\mathrm{OH}$ concentration for the pollutants released at 7:00 and 13:00 we can see that the $\mathrm{OH}$ 


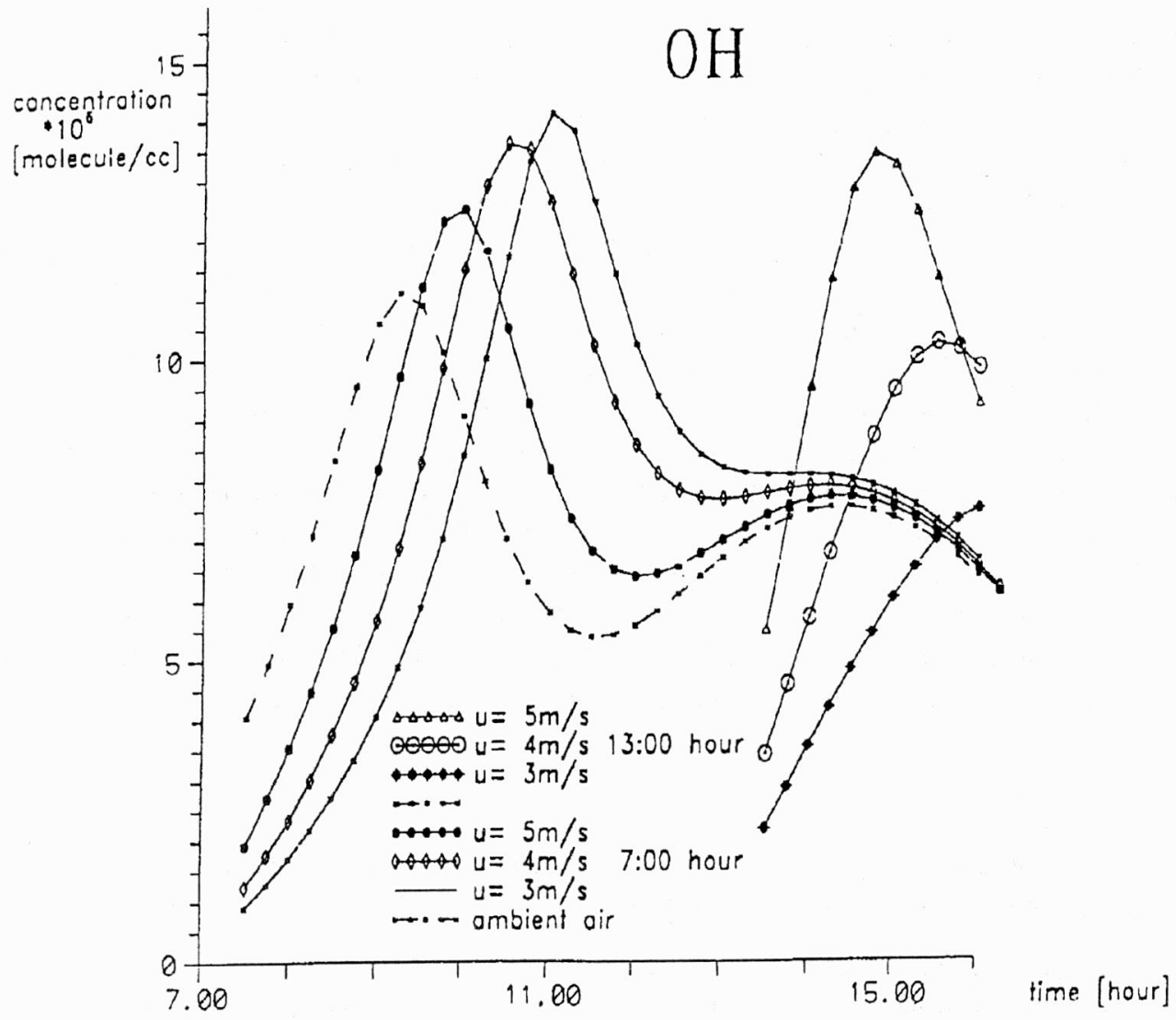

Fig. 2. Distribution of instantaneous $\mathrm{OH}$ concentration in the downwind plume axis for various wind velocities ( $u: 5 \mathrm{~m} / \mathrm{s}, 4 \mathrm{~m} / \mathrm{s}, 3 \mathrm{~m} / \mathrm{s}$ ) and fragile atmospheric stability (C).

Pollutants were emitted from the stack at 7:00 and 13:00

concentrations crucially depend on the time of the release of the pollutant to the atmosphere. For the pollutants released at 13:00 the maximum $\mathrm{OH}$ concentration under the conditions of fragile atmospheric stability and wind velocity of $3 \mathrm{~m} / \mathrm{s}$ is twice as small as the maximum value of this species for the pollution discharge at 7:00 under the same conditions and it is reached nearly one hour earlier measuring from the release time (figures 1,2). Comparing the distributions of $\mathrm{OH}$ concentration for the pollutants discharged at 7:00 in the plume axis for different atmospheric stabilities, we can state that the $\mathrm{OH}$ concentration in the plume axis is reached most quickly under the very unstable conditions, but the highest value of the peak concentration occurs at fragile stability (figure 1). As far as the influence of wind velocity on the $\mathrm{OH}$ concentrations is concerned, the peak $\mathrm{OH}$ concentration decreases with the wind velocity; however later the peak occurs closer to the stack. For the plume released at 7:00 the differences in the distributions of $\mathrm{OH}$ concentration due to the changes of the 
stability or wind velocity are rather small. In the case of the pollutants released at 13:00, the more unstable the atmosphere or the higher wind velocity, the higher values of the maximum $\mathrm{OH}$ concentration in the plume axis.

The peroxyl radical behaviour follows the pattern of the $\mathrm{OH}$ radical described above. The $\mathrm{HO}_{2}$ concentration in the plume axis increases with the travel time and peaks after few hours of transport of the pollutants from the stack. It is illustrated in figure 4 which shows the distributions of $\mathrm{HO}_{2}$ concentration in the plume axis for the plume released at 7:00 for different atmospheric stabilities and the wind velocity of $3 \mathrm{~m} / \mathrm{s}$. The dependence of the $\mathrm{HO}_{2}$ behaviour on the release time, atmospheric stability and the wind velocity qualitatively resembles the dependence of $\mathrm{OH}$ behaviour on these parameters; however in the case of plume released at 13:00, the $\mathrm{HO}_{2}$ concentration in the plume axis does not exceed the background $\mathrm{HO}_{2}$ concentration. For the plume discharged at 13:00 under the conditions of slightly stable atmosphere and wind velocity of $3 \mathrm{~m} / \mathrm{s}$, the peak value of $\mathrm{HO}_{2}$ concentrations in the plume axis is four times smaller than the maximum value of $\mathrm{HO}_{2}$ concentration for the emissions released at 7:00 under the same conditions. The peak values of $\mathrm{HO}_{2}$ concentrations in the plume axis for all conditions considered herein are given in the table.

Table

Instantaneous concentrations of $\mathrm{OH}, \mathrm{HO}_{2}$, and PAN in the plume axis (in molecule $/ \mathrm{cm}^{3}$ ) for various meteorological conditions and time of the release of the pollutant to the atmosphere

\begin{tabular}{|c|c|c|c|c|c|c|c|c|}
\hline \multirow{2}{*}{$\begin{array}{l}\text { Time of the } \\
\text { plume release }\end{array}$} & \multicolumn{2}{|c|}{ Meteorological situation } & \multicolumn{2}{|c|}{$\mathrm{HO}$} & \multicolumn{2}{|c|}{$\mathrm{HO}_{2}$} & \multicolumn{2}{|c|}{ PAN } \\
\hline & $s$ & u & $\begin{array}{l}\max c \\
\cdot 10^{6}\end{array}$ & $\tau$ & $\begin{array}{c}\max c \\
\cdot 10^{8}\end{array}$ & $\tau$ & $\begin{array}{l}\max c \\
\cdot 10^{10}\end{array}$ & $\tau$ \\
\hline $7: 00$ & very unstable & 3 & 12.80 & 3.25 & 12.10 & 5.50 & 14.32 & 5.25 \\
\hline $7: 00$ & unstable & 3 & 13.40 & 3.75 & 12.20 & 5.75 & 14.54 & 5.50 \\
\hline 7:00 & slightly unstable & 3 & 14.00 & 4.00 & 12.20 & 6.00 & 14.58 & 5.75 \\
\hline $7: 00$ & slightly unstable & 4 & 13.50 & 3.50 & 12.10 & 5.75 & 14.36 & 5.50 \\
\hline $7: 00$ & slightly unstable & 5 & 12.50 & 3.00 & 12.00 & 5.50 & 14.10 & 5.25 \\
\hline $13: 00$ & very unstable & 3 & 12.00 & 2.25 & 6.18 & 3.25 & 5.00 & 3.00 \\
\hline $13: 00$ & unstable & 3 & 9.50 & 2.50 & 4.45 & 3.75 & 4.02 & 3.50 \\
\hline $13: 00$ & slightly unstable & 3 & 7.40 & 3.00 & 2.89 & 4.25 & 4.50 & 4.00 \\
\hline $13: 00$ & slightly unstable & 4 & 10.00 & 2.50 & 4.25 & 3.75 & 4.42 & 3.00 \\
\hline $13: 00$ & slightly unstable & 5 & 13.20 & 1.75 & 7.00 & 3.00 & 5.24 & 2.25 \\
\hline
\end{tabular}

$s$ - atmospheric stability; $u$ - wind velocity at the anemometer height $(\mathrm{m} / \mathrm{s}) ; \tau$ - time of the maximum concentration occurrence measured from the moment of the plume release $(\mathrm{h})$.

$1 \mathrm{ppm}=2.46 \cdot 10^{13}$ molecule $/ \mathrm{cm}^{3}=40.9 \mathrm{MW} \mu \mathrm{g} / \mathrm{m}^{3}$ where $\mathrm{MW}$ is the molecular weight. 


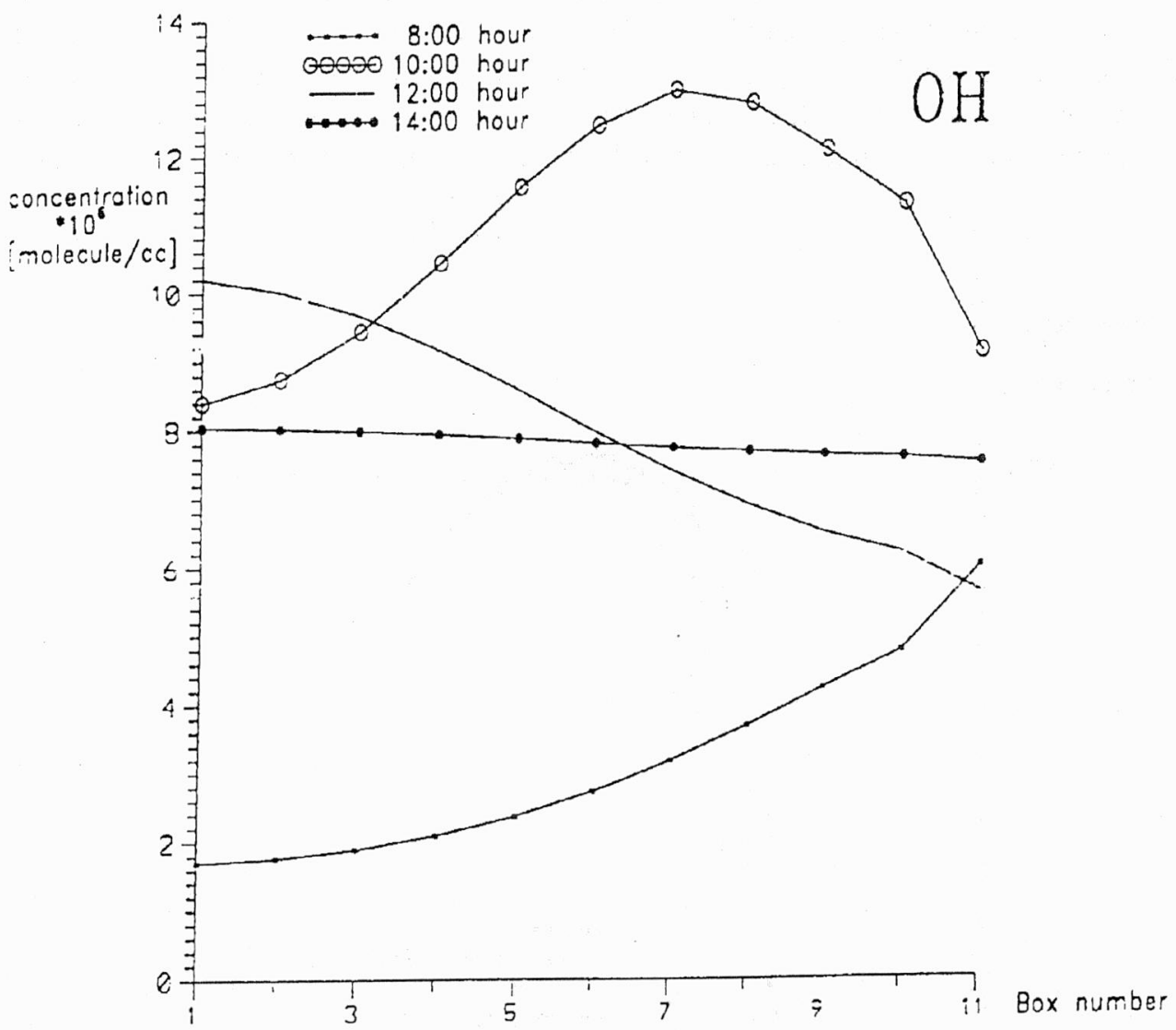

Fig. 3. Distribution of instantaneous $\mathrm{OH}$ concentration across the plume at various times:

8:00, 10:00 a.m., at noon and 14:00 p.m. Pollutants were emitted from the stack at 7:00 under the conditions of fragile stability and wind velocity of $3 \mathrm{~m} / \mathrm{s}$. The concentrations calculated in the plume axis and the ambient air are indicated respectively on the left and right (boxes 1 and 11)

The distributions of ozone concentration are shown in figures 5, 6, 7. The ozone concentration increases gradually with the plume travel time. There is no clear peak of ozone concentration. The variation of ozone concentration in the plume drifting downwind depends on the time of its discharge. For the plumes emitted at 7:00, the ozone concentration in the plume axis after few hours of transport exceeds the background value but for the discharge at 13:00 the ozone concentrations in the plume are all the time smaller than those in ambient air (figures 5,6). In such plumes, three stages of their development are also well defined (figure 7). Comparing the distributions of ozone concentration in the case of the plume discharge at 7:00 for different atmospheric stabilities, we can find that initially the ozone concentration increases quicker under the conditions of very fragile stability, but at the longer distances from 
the stack the situation changes and the more stable atmosphere, the higher the excess of ozone concentration compared to the ambient values (figure 5). There is a similar influence of the wind velocity on the behaviour of ozone concentration, i.e. initially the increase of the wind velocity gives the quicker increase in the ozone concentrations in the plume axis, but at the longer distances this tendency reverses - the smaller

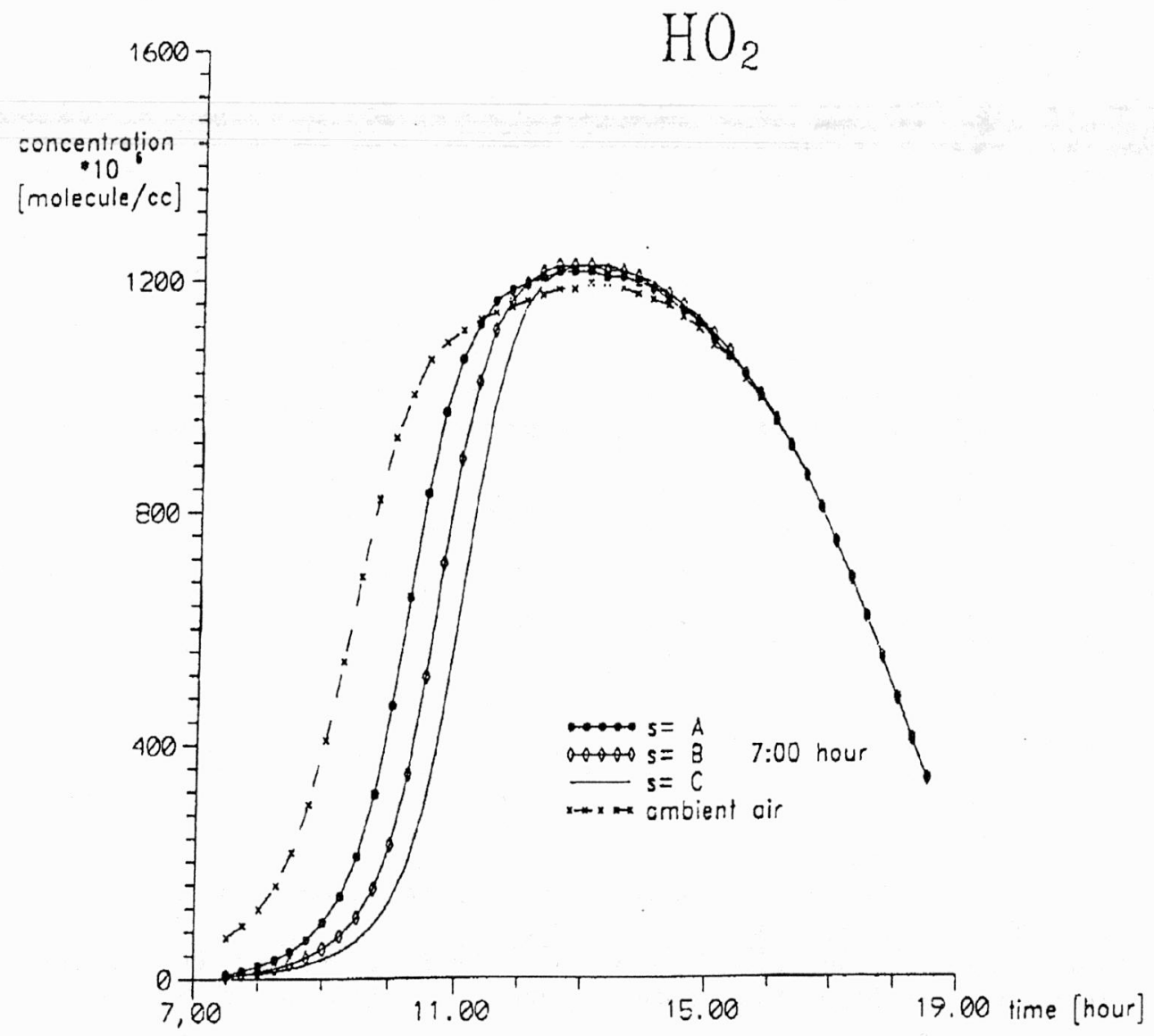

Fig. 4. Distribution of instantaneous $\mathrm{HO}_{2}$ concentration in the downwind plume axis for various atmospheric stabilities ( $\mathrm{s}$ : very unstable $-\mathrm{A}$, unstable $-\mathrm{B}$, slightly unstable $-\mathrm{C}$ ) and the wind velocity of $3 \mathrm{~m} / \mathrm{s}$. Pollutants were emitted from the stack at 7:00

wind velocity, the higher the ozone concentrations in the plume axis, which exceed the background value (figure 6). The excess of ozone concentration in the plume axis in relation to the background ozone level under the conditions of fragile atmospheric stability and the wind velocity of $3 \mathrm{~m} / \mathrm{s}$ reaches $17 \%$ of ozone background concentration. The variation of the distribution of ozone concentration for different atmospheric stabilities and wind velocities is rather small. For the plume discharged at 13:00, the 
ozone concentrations increase a bit quicker than in the case of the plume released at 7:00. The higher values are observed for more unstable atmosphere and higher wind velocities (figures 5,7 ).

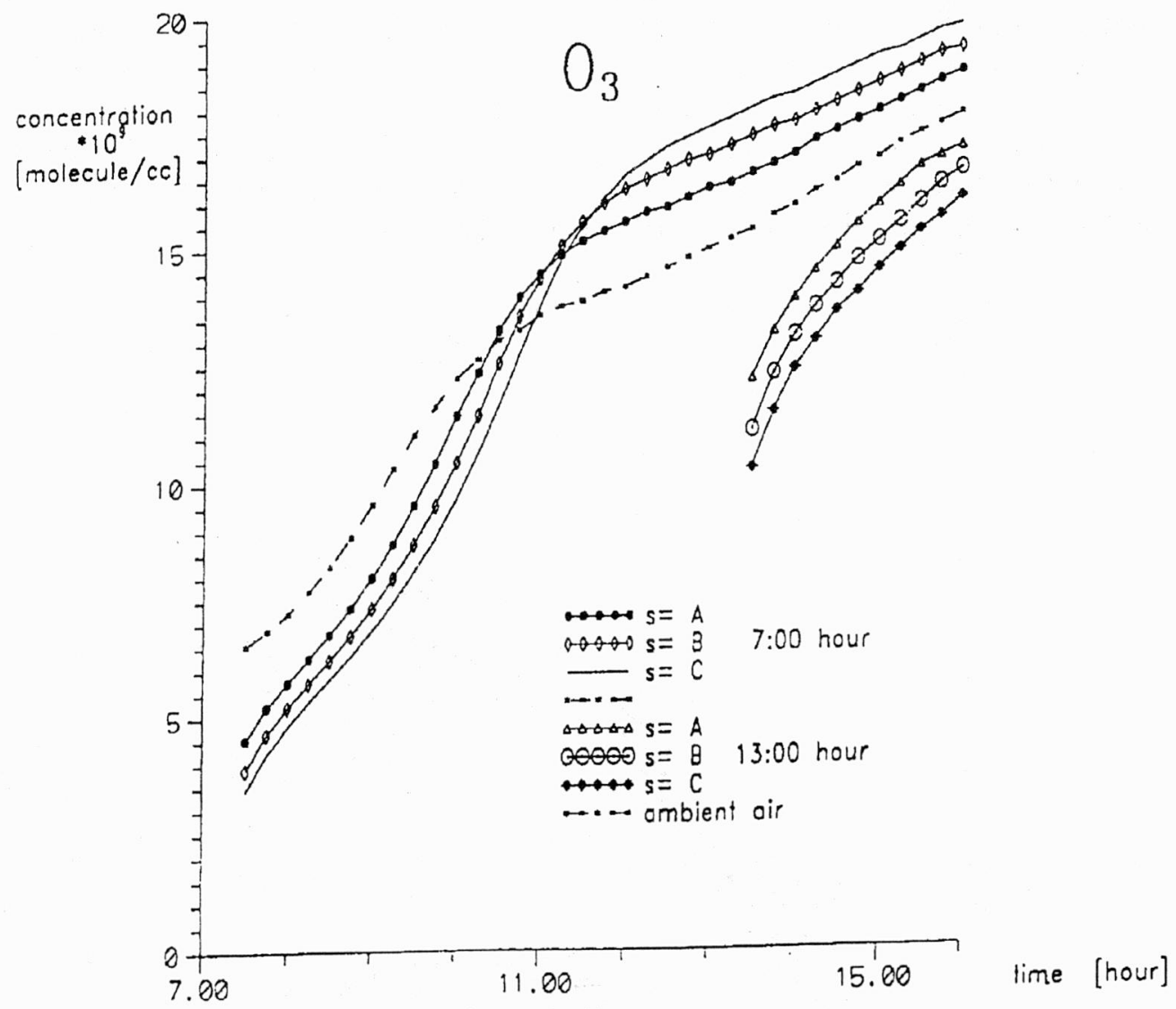

Fig. 5. Distribution of instantaneous $\mathrm{O}_{3}$ concentration in the downwind plume axis for various atmospheric stabilities (s: very unstable $-A$, unstable $-B$, slightly unstable $-C$ ) and the wind velocity of $3 \mathrm{~m} / \mathrm{s}$. Pollutants were emitted from the stack at 7:00 and 13:00

The depletion of the PAN concentrations in the plume axis is cancelled out gradually with the plume travel time. On the contrary to the curves illustrating ozone concentrations, the curves representing PAN concentration have a clear peak, especially for the plume released at 7:00. The distributions of the PAN concentrations in the plume axis for various atmospheric stabilities and the wind velocity of $3 \mathrm{~m} / \mathrm{s}$ are shown in figure 8 . The influence of the release time or meteorological parameters on the PAN concentrations is quantitatively similar to the influence of these parameters on the ozone concentrations. In this case, the time of release has also a considerable 
influence on the distribution of in-plume concentration. The peak value of PAN concentration in the plume axis for the plume released at 13:00 under the conditions of fragile stability and the wind velocity of $3 \mathrm{~m} / \mathrm{s}$ is nearly four times smaller than the maximum PAN concentration in the plume axis for the plume released at 7:00 under the same meteorological conditions. In the case of the plume released at 7:00 the more stable atmosphere or lower wind velocity, the higher the excess of PAN concentrations in the plume axis compared to the ambient values. For the plume released at 13:00, the in-plume PAN concentrations are always smaller than those in ambient air and the more unstable atmosphere or the higher the wind velocity, the higher the inplume PAN concentrations. The peak values of PAN concentrations in the plume axis for all conditions considered herein are shown in the table.

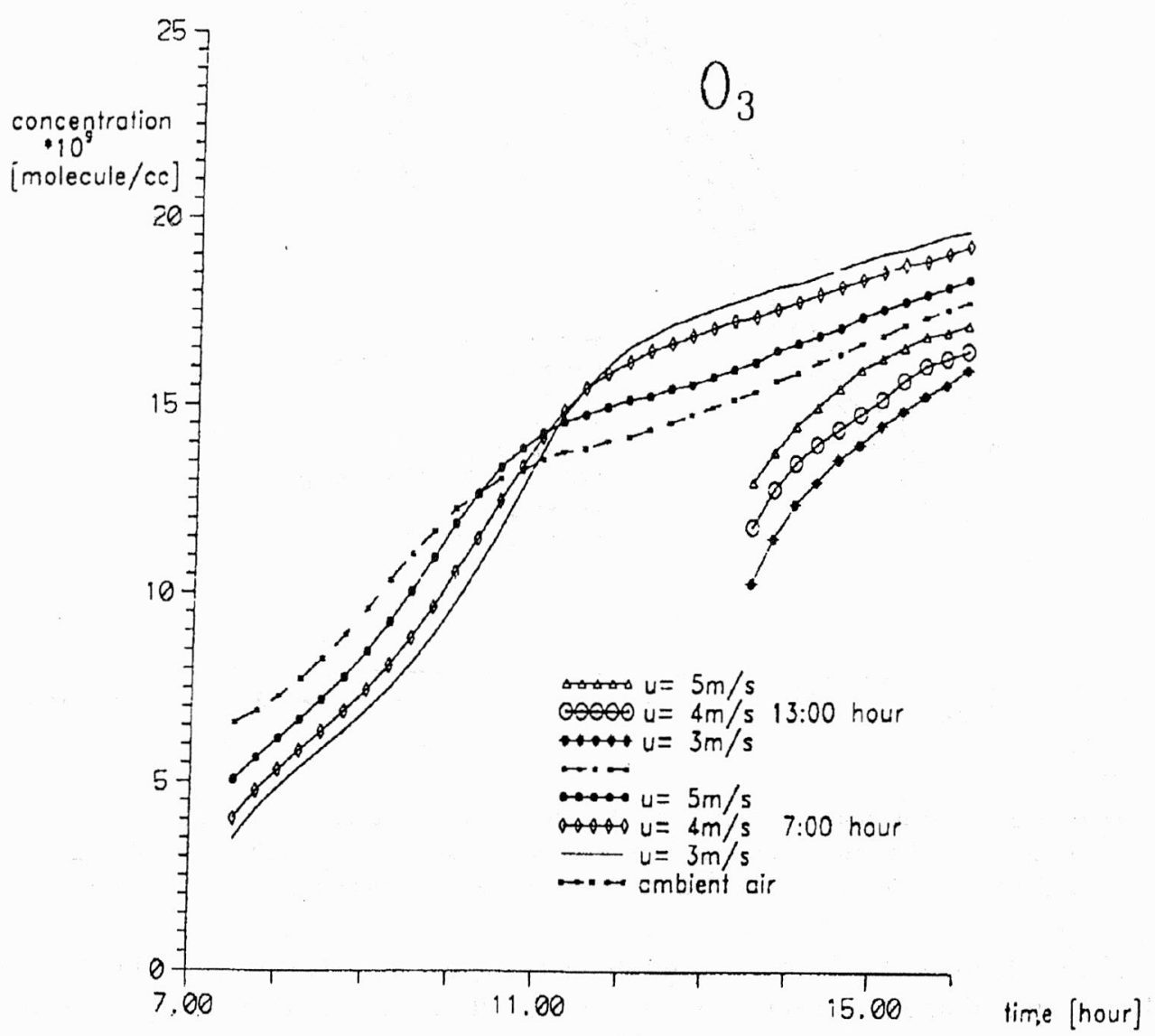

Fig. 6. Distribution of instantaneous $\mathrm{O}_{3}$ concentration in the downwind plume axis for various wind velocities ( $u: 5 \mathrm{~m} / \mathrm{s}, 4 \mathrm{~m} / \mathrm{s}, 3 \mathrm{~m} / \mathrm{s}$ ) and fragile atmospheric stability (C). Pollutants were emitted from the stack at 7:00 and 13:00 


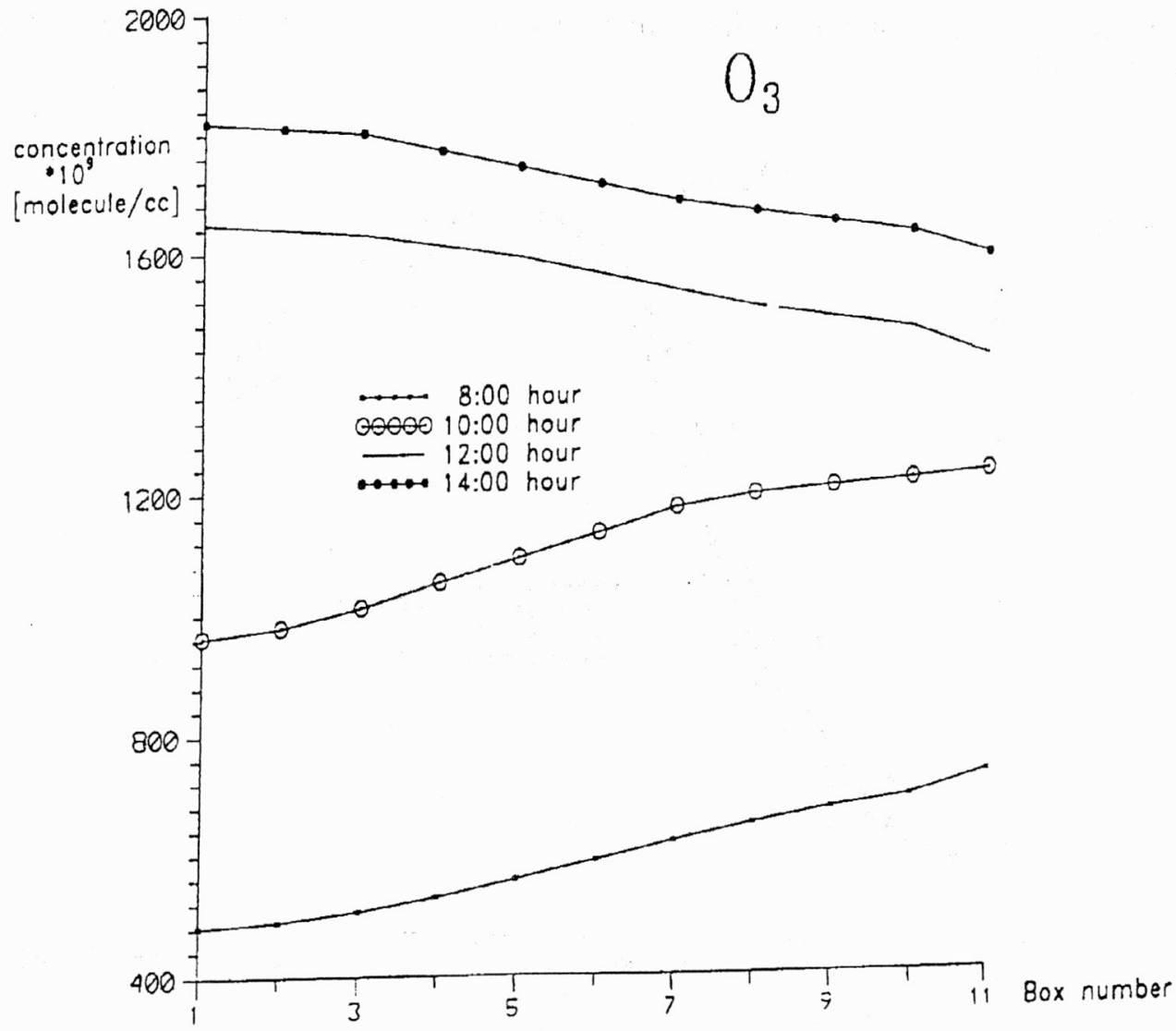

Fig. 7. Distribution of instantaneous $\mathrm{O}_{3}$ concentration across the plume at various times: 8:00, 10:00 a.m., at noon and 14:00 p.m. Pollutants were emitted from the stack at 7:00 under the conditions of fragile stability and wind velocity of $3 \mathrm{~m} / \mathrm{s}$. The calculated concentrations in the plume axis and the ambient air are indicated respectively on the left and right (box 1 and 11)

\section{CONCLUSIONS}

Based on the results of the MRPM model simulations of the reactive plume emitted from the conventional power station under the meteorological conditions typical of a summer, sunny day in Poland, the following conclusions can be formulated:

1. The above characteristic of the reactive plume evolution is typical of the conditions studied, i.e. for a summer day with sunshine and warm weather. The results of the MRPM model simulations are consistent with the results of the computer 
simulations carried out under the similar conditions using other reactive plume models [1]-[3].

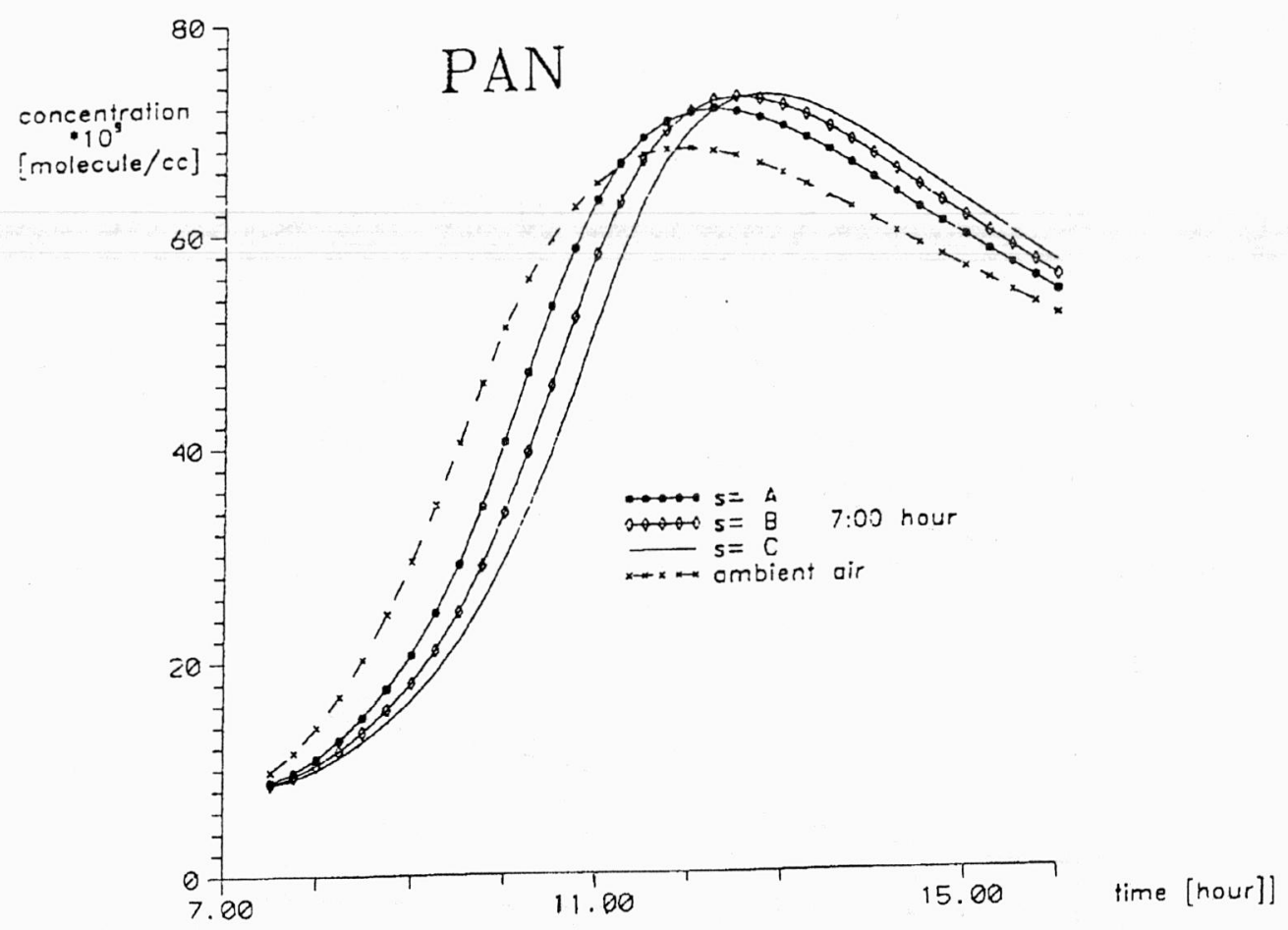

Fig. 8. Distribution of instantaneous PAN concentration in the downwind plume axis for various atmospheric stabilities (s: very unstable $-\mathrm{A}$, unstable $-\mathrm{B}$, slightly unstable $-\mathrm{C}$ ) and the wind velocity of $3 \mathrm{~m} / \mathrm{s}$. Pollutants were emitted from the stack at 7:00 hour

2. There are significant differences between the diluting plumes and the ambient atmospheric air with respect to the concentrations of such radicals as $\mathrm{OH}$ and $\mathrm{HO}_{2}$ and secondary species such as $\mathrm{O}_{3}$ and PAN. These differences arise from the greater $\mathrm{NO}_{x}$ concentrations in the plumes.

3. The concentrations of radicals and photochemical oxidants in the typical coalfired power plant plume vary as the plume moves downwind. At short plume drift the concentrations of radicals and photochemical oxidants are very low due to the large excess of $\mathrm{NO}_{x}$ over hydrocarbons. The concentrations of radicals and photochemical oxidants increase significantly at some distance from the stack, when the ratio of hydrocarbons, entrained from the background, to $\mathrm{NO}_{x}$ becomes more balanced. During further downwind drift, when the ratio of $\mathrm{NO}_{x}$ to hydrocarbons approaches the level typical of the given background, the concentrations of radicals and photochemical oxidants decrease to the ambient values. 
4. The maximum values of in-plume radicals and the concentrations of secondary species vary somewhat depending on the input parameters, i.e. on the wind speed, atmospheric stability and time of the release of the pollutants to the atmosphere. Of all the factors considered the time of the release of pollutants to the atmosphere has the strongest influence on the plume behaviour. This can be explained by the fact that many of the chemical processes occurring in the reactive plumes are connected with photochemical reactions. The rates of the photochemical reactions depend on the solar radiation intensity and vary within the day.

\title{
REFERENCES
}

[1] Hov O., ISAKSEN J.S.A., A chemical model for urban plumes: test for ozone and particulate sulphur formation in St. Louis urban plume, Atm. Env., 1978, 12, 599-604.

[2] STEWARD D.A., LiU, M.K., Development and application of a reactive plume model, Atm. Env., 1981, 15, 2377-2393.

[3] DERWENT R.G., Computer modelling studies of photochemical air pollution formation in power station plumes in the United Kingdom, AERE Report R-10631, 1981.

[4] MARKIEWICZ M., The multibox reactive plume model with variability of meteorological parameters taken into account. Part I. Model formulation, Env. Prot. Eng., 1996, Vol. 22, No: 1-2, pp. 40-53.

[5] MARKIEWICZ M., The multibox reactive plume model with variability of meteorological parameters taken into account, AEA Technology, Warsaw University of Technology Report, 1994.

[6] Guidance of calculating the state of the air pollution contamination in the vicinity of the point sources (in Polish), Warszawa, PZITS, 1981/1983.

[7] DeRwent R.G., Hov O., Computer modelling studies of photochemical air pollution in north-west Europe, AERE Report R-9434, 1979.

[8] Garland J.A., Principles of dry deposition: application to acidic species and ozone, VDI-Berichte, Nr 500, 1983.

[9] CURTIS A.R., SWEETENHAM, W.P., FACSIMILE release H user manual, AERE Report R-11771, 1985.

[10] COCKS A.T., FletCHER J.S., Major factors influencing gas-phase chemistry in power-plant plumes during long-range transport. I. Release time and dispersion rate for dispersion into a 'rural' ambient atmosphere, Atm. Env., 1988, 22, 663-676.

[11] FInLAySON-PITTS B., PITTS J., Atmospheric chemistry: Fundamentals and experimental techniques, John Willey and Sons, 1986.

\author{
WPLYW CZASU WYRZUTU ZANIECZYSZCZEŃ DO ATMOSFERY \\ I WARUNKÓW METEOROLOGICZNYCH NA POWSTAWANIE ZANIECZYSZCZEŃ \\ WTÓRNYCH W SMUGACH GAZÓW KOMINOWYCH \\ EMITOWANYCH Z KONWENCJONALNYCH ELEKTROWNI WĘGLOWYCH
}

Zanieczyszczenia wtórne, wśród których można wymienić między innymi: ozon, PAN, aerozole kwasu siarkowego i azotowego, powstają $w$ powietrzu atmosferycznym $w$ wyniku reakcji chemicznych z zanieczyszczeń pierwotnych, to jest $\mathrm{z}$ bezpośrednio emitowanych do atmosfery zanieczyszczeń, takich jak: dwutlenek siarki, tlenki azotu, węglowodory.

Zjawisko to przebiega $z$ dużym nasileniem w słoneczne, bezchmurne, letnie dni. Jak się obecnie uważa, zanieczyszczenia wtórne są bardziej szkodliwe dla środowiska i zdrowia ludzi niż zanieczyszcze- 
nia pierwotne. Niniejsza praca mówi, jak modelować powstawanie zanieczyszczeń wtórnych w smugach gazów kominowych emitowanych z elektrowni węglowych. Jej celem było zbadanie rozkładów zanieczyszczeń wtórnych w smugach gazów elektrownianych w zależności od warunków środowiskowych, tj. w zależności od pory wyrzutu zanieczyszczeń do atmosfery i warunków meteorologicznych. W symulacjach wzięto pod uwagę sytuacje meteorologiczne typowe dla letniego słonecznego dnia w Polsce. W obliczeniach wykorzystano model MRPM (Multibox Reactive Plume Model) przeznaczony do badania ewolucji smugi gazów kominowych emitowanych z wysokich punktowych źródeł emisji opracowany przez Markiewicz (1996). W pracy przedstawiono kolejno: skrócony opis modelu MRPM, zakres i wyniki symulacji. 